\title{
POLICY EFFECTIVENESS OF COMMUNITY-BASED WASTE MANAGEMENT IN THE CITY KEDIRI
}

\author{
Yenik Pujowati \\ Departement of Social and Political Sciences \\ University of WijayaKusuma Surabaya \\ Email: yeniworo@gmail.com
}

\begin{tabular}{l}
\hline \hline Article Info \\
\hline Article history: \\
Received Apr 3, 2021 \\
Revised May 13, 2021 \\
Accepted June 27, 2021
\end{tabular}

Keywords:

Policy Effectiveness

Community-based Waste

Management.

\begin{abstract}
Background; Community consumption patterns contribute to creating increasingly diverse types of waste and the total waste produced, as well as the lack of public awareness in community-based waste management. The policy of the local government of the city of Kediri to provide infrastructure for waste management includes; storage, collection, transfer, transportation and final disposal (TPA). The role of the DLHKP in Kediri City is to provide training and assistance aimed at training residents so that they can use waste and manage waste wisely, especially household waste. Research methods; This type of research uses descriptive and qualitative approaches, researchers try to describe the object of research through observation and analysis of primary data and secondary data. The results of this study indicate that the implementation of community-based waste management socialization in Kediri City has not run optimally. Regarding the infrastructure for the pattern of waste transportation in the city of Kediri, it has not been running effectively and efficiently, due to the lack of a waste transport fleet and limited human resources in the field of waste experts. Conclusion; the effectiveness of community-based waste management policies in the city of Kediri, there are still few people who take part in the waste management process because people do not really understand the concept of waste management
\end{abstract}

This is an open access article under the CC BY-SA license.

\section{Corresponding Author: \\ Yenik Pujowati \\ University of WijayaKusuma Surabaya \\ Email: yeniworo@gmail.com}

\section{INTRODUCTION}

Garbage is a big problem, a national problem even universal problem, Along with the times, more rapid population growth especially in urban areas increasingly dense population increase. With increasing population and activity means the higher needs of the community, both the needs of primary, secondary and tertiary needs, packs consumable product into the garbage, no matter how small it is a bunch of garbage that has been unused material. The category of garbage there are two organic and inorganic waste, organic waste such as food scraps, vegetables, fruits or other forage, waste treatment can be used directly, without going through a certain process such as animal feed and compost, while the inorganic waste such as pieces of glass, paper, metal, plastic, rubber and other inorganic materials, can be overcome by reducing use or even recycling. (Rezky Amelia Salinding, et, al.2016)

The government's policy No 18 of 2008 on Waste Management has the intent that the waste management aims to improve public health and environmental quality as well as to utilize waste as a resource. Policy No. 3 of 2015 concerning Waste Management in Kediri. In addition, the regulation concerning waste management are also necessary legal certainty, clarity of responsibility for both the central government, local governments and communities and businesses that waste management can be a professional, effective and efficient. The problem of waste until now has always been one of the main issues in every regency or city. Waste management is an integral part in the management of sanitation settlements. Where the sanitation conditions of good and healthy settlements are determining the degree of public health. Therefore, to create a healthy sanitation indispensable settlement patterns of effective waste management.

Journal homepage: https://bajangjournal.com/index.php/IJSS 
The waste management policies at TPS 3R (reduce, reuse, recycle) that have been carried out in several cities before are also still not effective in their implementation. (Fallita R. W, et al. 2021). The effectiveness of proper waste management be synergistic and integrated so that it is effective and able to achieve the goal of waste reduction targets in each area. Waste management policy on settlements, the community as a source of waste generation should be involved in waste management activities consist of sorting at source, waste processing with the $3 \mathrm{R}$ principle, maintain the cleanliness of the environment, comply with the rules of garbage disposal and was active in waste management socialization environment. In a community-based waste management, objectives, namely the reduction of the amount of waste ending up in landfill. These objectives can be achieved if people pick through the trash and implement the $3 R$ principles ranging from household items such as reducing the use of disposable items (reduce), reuse items that still feasible to use (reuse), and process waste into new products that are beneficial (recycle) so garbage will be taken to the landfill becomes less than the amount of waste generated. (Rezky Amelia Salinding, et al.2016).

Reviewing the above explanation, community-based waste management policy is needed to support the performance of domestic waste management in the town of Kediri to maintain the cleanliness and health of the surrounding environment. Therefore, this study was conducted to identify the effectiveness of community-based waste management policies carried out by households by comparing the volume of waste in a Regency/City from time to time and continues to increase along with population growth, including in the City of Kediri. In addition, people's consumption patterns contribute to the creation of increasingly diverse types of waste and the total amount of waste produced. On the other hand, land for waste disposal is increasingly difficult to obtain, as a result of urban growth causing a high volume of waste generated by the community. There has been an increase in the volume of waste disposed of in the TPA, due to ineffective waste management habits, failure to recycle and reuse used goods, and the inability of the community. This research is expected to benefit the local government to take a decision regarding the application of the principles of the $3 \mathrm{R}$ (reduse, reuse, recyle) in the house hold. Community participation in managing household waste such as waste sorting efforts, application of $3 \mathrm{R}$ principles and the percentage reduction in the amount of waste going to TPS and TPA within a certain period of time are the main focus of this research.

\section{METHODS}

This research is a descriptive qualitative research, namely research that collects data in the form of words, pictures, and numbers. The author tries to find out the symptoms that occur in the object of research that takes place at a certain time and then describes these events with data obtained from observations and research in the field, (W. C. John, 2014:35).

The research location is in the city of Kediri, at the Department of Environmental Sanitary and Landscaping (DLHKP) of Kediri City, East Java.

Research informants are subjects or parties who know or provide information or completeness regarding the object of research. In this study, using research informants through key informants where researchers already understand the initial conditions of the research object and research informants. The informants selected based on their function and position are as follows; through the Coordinator of the Environmental Cleanliness and Landscaping Service (DLHKP) of the City of Kediri, the Head of the Waste Reduction and Utilization Section, the Head of the Facilities and Infrastructure Section, the Head of the Kediri City Waste Bank, the community, RT, RW and community leaders in the City of Kediri.

Types and sources of data, namely primary data and secondary data, data collection techniques This study uses data collection techniques as follows; interview, observation, documentation, literature study and field study.

Data Analysis, In analyzing the data, the authors first collecting the necessary data in this study. Once the information is required in this study collected, the method of data analysis using qualitative descriptive method, which examines the descriptive data.

\section{RESULTS AND ANALYSIS}

1. The Effectiveness of Community-Based 3R Waste Management Policy in the City of Kediri through; a. Implementation of Community-Based Waste Management Socialization in the City of Kediri.

The Department of Environment, Hygiene and Landscaping of the City of Kediri held a community-based waste management socialization. Waste management must start from the source is household waste sorting by type. Organic waste can be used as compost material and then the inorganic can be sold to waste banks. We should be able to sort out the garbage, garbage which can be composted and that we can sell to the bank. DLKPH officer of Kediri explained that the trash was sorted by type, there are organic and there are also inorganic. Organic waste comes from the food we consume, such as the skins of vegetables and fruit. While inorganic waste that is not derived from food and can not be composted, such as plastic, rubber, and tin. 
Based on research data, each person in the City of Kediri produces 0.5 kilograms of waste every day and every day the City of Kediri produces approximately 145 tons of waste. Therefore with this Perwali expected community can actively participate in waste management and sorting of waste. The community must also apply the paradigm of how waste can be of economic value, (Nur Indrianti, 2016). The socialization activity was carried out in front of the employees at the Kediri City Hall. The event also promoted Perwali No. 36 in 2018 on complaints management service environment of the Government of Kediri. The Perwali explains the spaces for expressing aspirations or complaints. Both verbal delivery and through the voice of citizens and social media. In the socialization, two speakers were presented, namely the Head of the Communication and Information Resources Development Division of the City of Kediri and the Head of the Section for Waste Utilization and Hazardous Waste Handling DLHKP.

The Department of Environment, Cleanliness and Parks of Kediri City reduces 3R waste (reduce, reuse, recycle) by providing $3 \mathrm{R}$ waste recycling training as shown below:

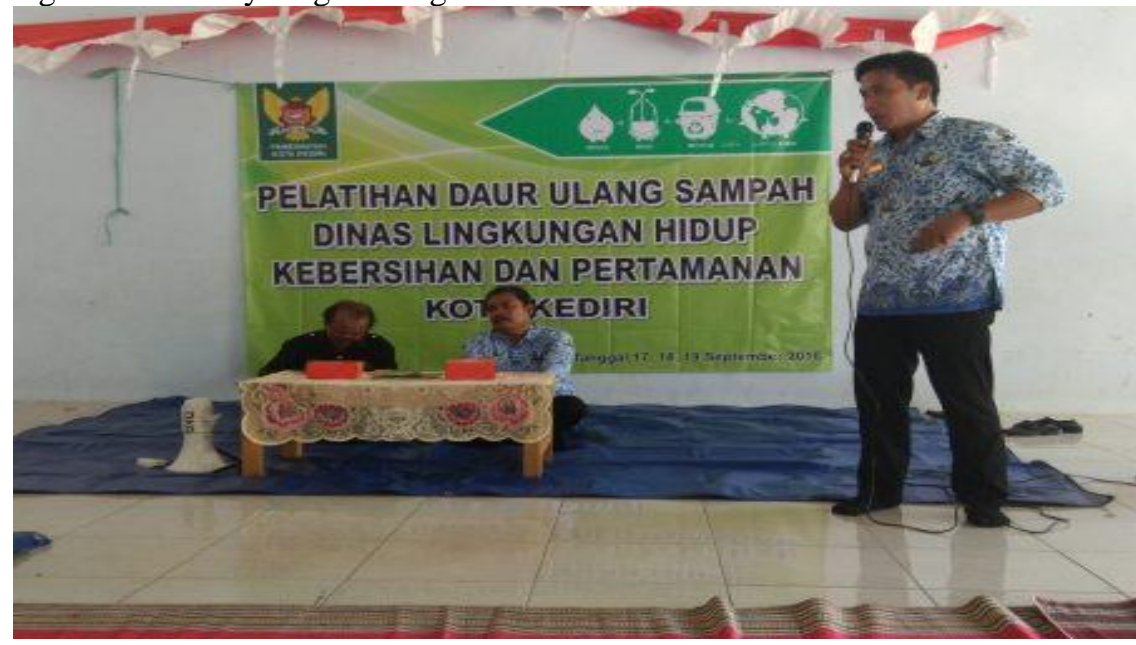

Picture; Garbage Recycling Training

Source: Department of Environmental Sanitary and Landscaping of Kediri City 2018

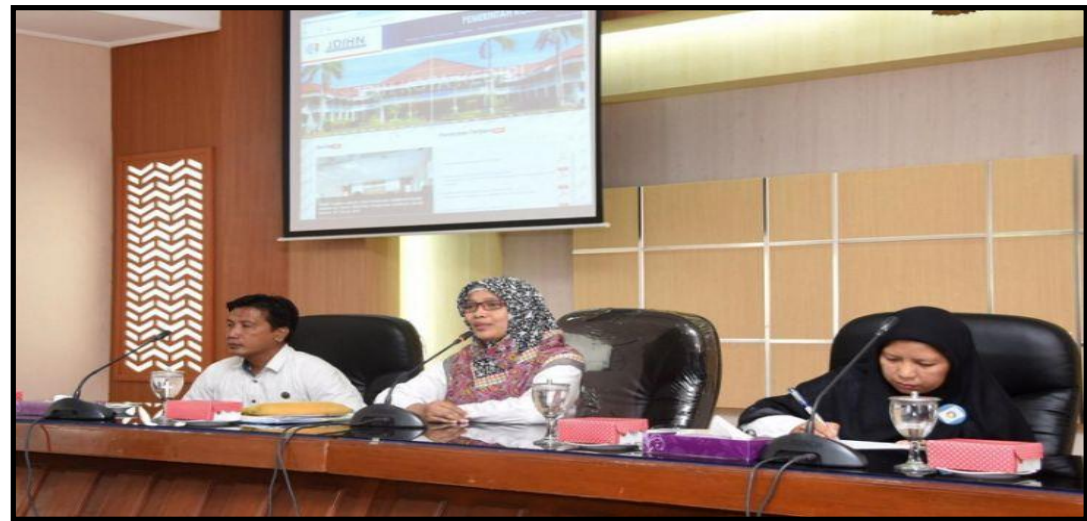

Picture: Mayor socialization Regulation N0 352018 on Policies and Strategies of Kediri in Household Waste Management and Waste Household kind in Kediri City Hall. East Java.

Source: Department of Environmental Sanitary and Landscaping of Kediri City 2018.

https://www.kedirikota.go.id/p/dalamberita/3378/pemkot-kediri-buat-aturan-kurangi- sampah.

The effectiveness of waste management policies through waste recycling training aims to train the community so that residents can use proper waste management, can produce such as organic waste that can be processed into compost, even into gas fuel. Effectiveness of waste management can increase the community's economy through waste banks and can utilize waste that has economic value. The Department of Environment, Cleanliness and Parks in Kediri City has conducted waste reduction through waste recycling training which was opened directly by the Head of Cleanliness \& Waste Management 3R (reuse, reuse, recycle) which is located in the Sri Wilis waste bank in Pojok Village, Mojoroto District, Kediri City. This training aims to train residents so that they can use waste and manage waste wisely, especially household waste, which refers to Law No. 18 of 2008 concerning waste management. Kediri 
ISSN: $\quad$ DOI:

City Regulation No. 3 of 2015 concerning Waste Management. The Kediri City Government (City government) through the Parks Hygiene Environmental Service, Kediri City Government held a waste recycling training which was opened directly by the Head of Cleanliness \& Waste Management, which took place at the Sri Wilis waste bank in the corner village, Mojoroto District, Kediri City.

To achieve the success of Waste Management and Recycling of Waste 3R (reduse, reuse, recycling), some of the things that need to be considered in the handling of garbage in the settlement environment are community participation as manufacturers of disposal to response other supporting factors. The participation of the community in waste management can be carried out through the participation of the community concerned. In increasing the participation of the community, a motivator can motivate the community to play an active role in every activity. The participation of the community in waste management can be done through socialization, counseling, training, pilot and development activities. The socialization held with the target of the community, cadres of garbage banks and the school environment at the high school level in the city of Kediri.

The policy on waste management that has been separated from the level of household waste has not been implemented properly. However, the fact is that not many have done the sorting of plastic waste, as well as organic and inorganic waste, on this occasion, we invite representatives from each community and family to be given socialization about $3 \mathrm{R}$ waste management, Not only sorting waste, but the community is also invited to minimize waste management and be able to recycle household waste. One example of simple steps to reduce the use of drinking straws and plastic cups, reducing the use of plastic bags. As we give people an understanding of how to manage waste plastics, can also be a source of additional income, in plastic waste sorting to be done by empowering people through the $3 \mathrm{R}$ program through (reduse, reuse, recyle), (Utami, B. D. et. al. 2008)

Implementation assistance program required qualified human resources capable of acting as a facilitator, communicator and motivator during the program and serve as a consultant as needed by the group. Attitude and behavior of the community in waste management $3 R$ through this mentoring. The results of the $3 R$ waste management assistance in the City of Kediri that have been carried out for two years have not been able to optimally change people's attitudes and behavior in managing waste. Most people are still burdened with waste sorting. In some households there are still people who throw garbage into the composter is mixed. This is due to the low level of public awareness and knowledge about waste management. the difficulty of finding the role of the community to dispose of waste in its place and maintain cleanliness and the dangers caused by waste.(Nur Indrianti:2016). DLHKP Kediri City implements $3 \mathrm{r}$ waste management (reuse, reuse, recycle) through training on recycling dry waste into handicraft materials that produce community-based economic value in Kediri City as follows:

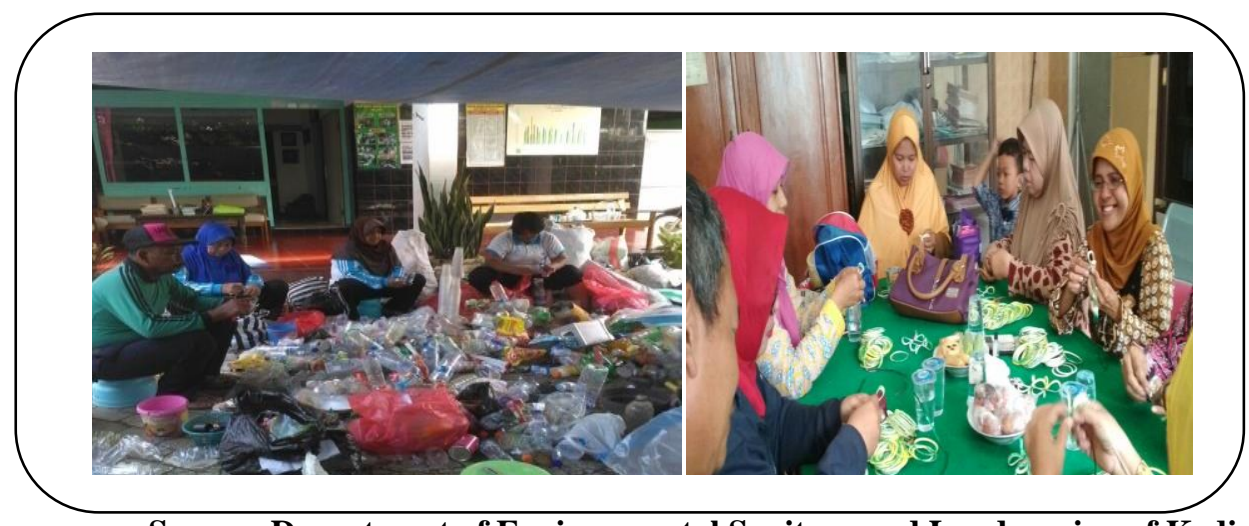

Source: Department of Environmental Sanitary and Landscaping of Kediri City 2018

The role of the Department of Environment, Cleanliness and Parks in Kediri City holds regular meetings to increase community participation in waste management by using $3 \mathrm{R}$ (reuse, reuse, recycle) using used goods that can be recycled and processed into useful goods. One way to use second-hand goods to be reused be useful or versatile item can also be processed into goods that can be traded. Moreover, it can take advantage of second-hand goods around us to create new jobs and the preservation and cleanliness of the environment around us. Effectiveness of waste transport from home to home to TPS is running normally, infrastructure, transportation of garbage has done well, now biweekly garbage collection has been done weighing in the $\mathrm{Rt} / \mathrm{Rw}$ fortnightly on call a part of the stall, for weighing is done every people have started doing the collection, separation, extraction and weighing the trash. Collection and waste management carried out by citizens through $\mathrm{Rt} / \mathrm{Rw}$, garbage bank group, now residents are already aware of the trash can help middle class economy. Residents are routinely performed in the bank-bank deposit trash or garbage collection points. External constraint is the level of public awareness of the litter that is still lacking, ignorance of the public on regional regulation, infrastructure for waste management is inadequate. The effectiveness of community- 
based waste management policies in Kediri City has not run effectively and efficiently. (Rezky Amelia Salinding, et al. 2016.) Jurnal Administrasi Publik. Vol 3, No 41.

The following are the activities of the Department of Environment, Hygiene and Parks (DLHKP) of Kediri City socializing with the community to clean up the scattered garbage in the klotok final disposal site (TPA) Kediri city, as shown in the following picture:

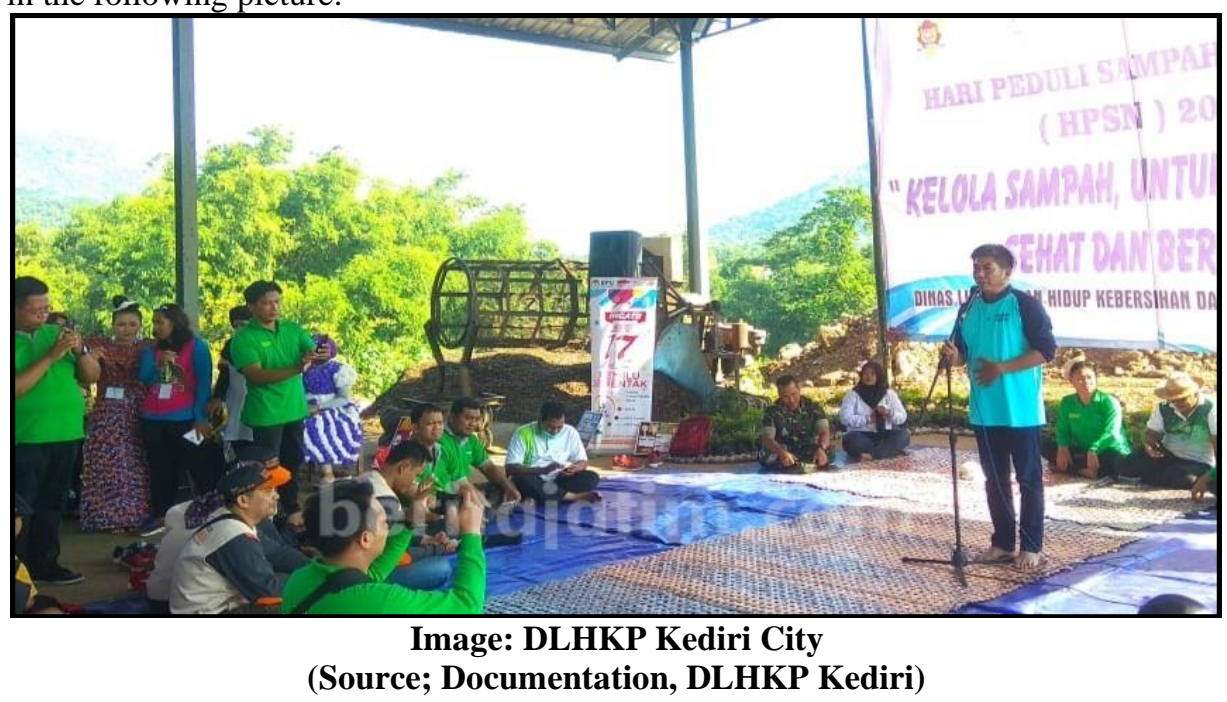

The effectiveness of community-based waste management policies in the City of Kediri, residents together with the Environment, Hygiene and Parks Service (DLHKP) clean up the waste that is scattered in the final disposal site (TPA). At least 300 residents were involved in this action. Covering students, garbage bank cadres and environmentalists, activities of the theme 'Urban Waste for Clean, Healthy and Worth. They clean up the garbage scattered on the road towards the landfill. In addition to clean up the waste of various activities were held in the following events like workshops biopori processing as a composter agitator and fashion with clothes from recycled waste and recycled exhibition. Government Policy No. 81 of 2012 on the management of household waste and Kediri City Regulation No. 3 of 2015 about waste management, related to the implementation of the 3R waste management program through the object and purpose of socialization is as follows; a). Dissemination to the public at large and the cleanliness of the cadres and cadres garbage bank to continue to remember the importance of hygiene and waste management in order to create a healthy and clean environment. b). Provide insight and understanding that trash is our common responsibility if it is managed will be a blessing and if allowed to be a disaster. c). Providing training recycling inorganic waste into works of craft that has benefits and economic value. The effectiveness of waste management policies with the application of the 3R concept (reduce, reuse, recycle) needs assistance that can provide direction and motivate people to manage waste in their environment from the source to recycling waste into something useful.

\section{Waste Management Facilities and Infrastructure in Kediri City.}

The effectiveness of community-based waste management policy in support with the financing aspects of the proposition and infrastructure needs of solid waste. In view of the operating and maintenance costs for the operator of facilities and infrastructure needs of waste is relatively very high. Financing for the needs of waste management facilities and infrastructure is derived from budget funds, while some infrastructure such as landfill II and TPS3R financed from state funds associated with the budgeting is not running optimally and still limited funds. (Yenik Pujowati, et al:2019) International Journal of Mechanical Engineering and Technology (IJMET).

Inadequate budget, especially from APBD. Provision of infrastructure in waste management, especially TPST 3R must distinguish between the organic and inorganic waste needs a budget that does little for example, only in batu budgeted Rp 300 million for a waste processing machine, while the tools needed 5 units. This automated budgeting requires a lot, also not uncommon to wait for the budget period next year so had to wait a few moments making waste processing becomes ineffective. (Fallita R,W. et al) 2021.

The effectiveness of community-based waste management policy in the town of Kediri supported DLKP Standard Operational Procedures as a guide or reference activity to perform job duties in accordance with its function. SOP their community-based waste management in the town of Kediri DLHKP run effectively and efficiently, consistent, standardized and systematic, but on the other hand the lack of community-based waste management SOP does not run "effective and efficient" (Winarsih, N, W, E. et al, 2019). Regional regulation policy no. 32015 on waste 
ISSN: $\quad$ DOI:

management Kediri. Under the regulation is very important for strengthening of community-based waste management improvement. To support the technical aspects of waste management operations through, Stockpiling, container, collection, transfer and transport, separation, processing and information to the landfill of conditions and service level of each polling station not optimum, each polling station where the waste transportation which is managed by the DLHKP has been scheduled according to the procedure, however, there has been a delay in transporting waste due to the very limited condition of the waste transport equipment in DLHKP and the current situation is damaged and inefficient to operate, thus waste management services at DLHKP Kediri City are also in supported by the overall waste management system described as follows:

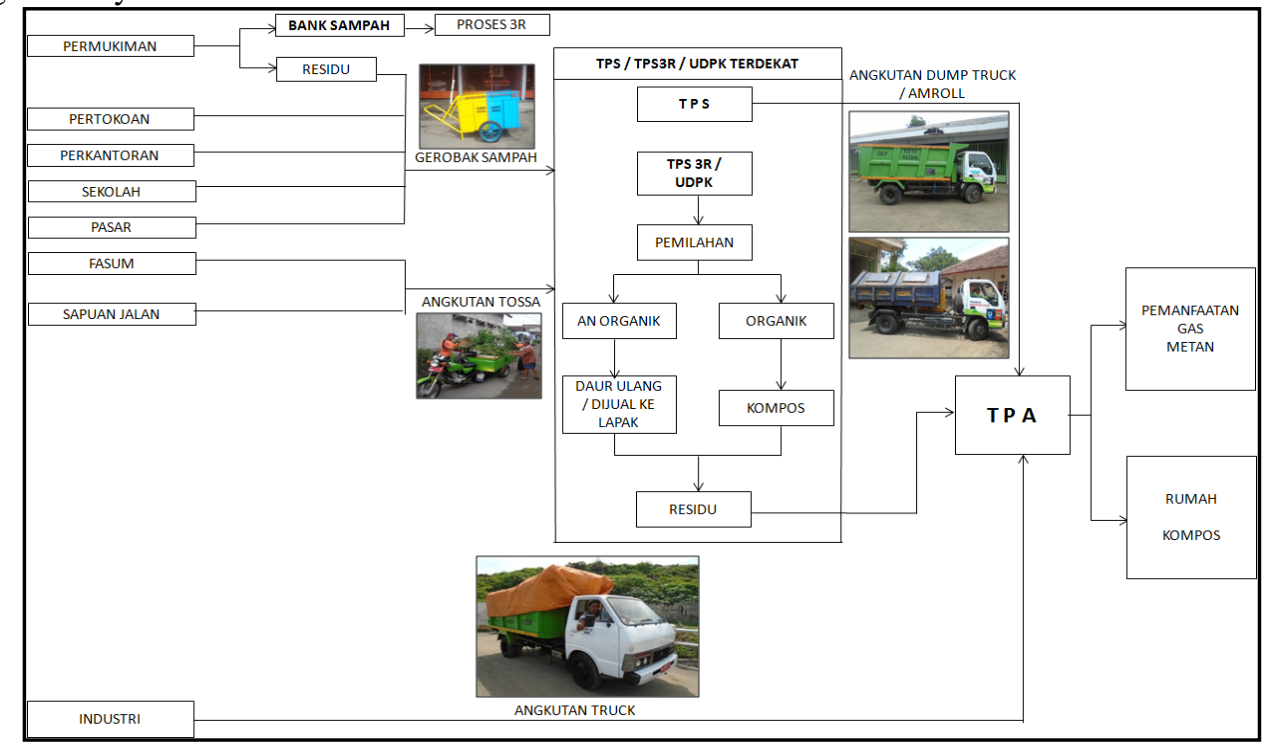

Image: Kediri City Waste Management System

Source: Department of Environmental Sanitary and Landscaping of Kediri City 2017

Based on the picture above, it is known that the overall waste management system is all activities related to waste control starting from collection, transfer and transportation, management and disposal of waste, taking into account environmental health, economy, technology, conservation, aesthetics and environmental factors. others that are closely related to community response. The explanation is related to Law no. 18 of 2008 on waste management as a systematic, comprehensive and sustainable which includes waste reduction and handling. In addition, supported the technical aspects of the operational effectiveness of community-based waste management policy through:

1. Garbage container.

Based on the results of the study, it is known that the implementation of waste processing by the Department of the Environment, Hygiene and Parks of Kediri City has been carried out well, that the government of the city of Kediri has provided a place of storage according to the type of trash can, such as plastic trash cans, paper trash cans, B3 trash cans organic trash cans and non-organic trash cans. On the other hand, it is supported by facilities, funds, human resources, technology, transportation facilities and infrastructure. However, judging from the activities of collecting waste in the community, there is still a lack of public awareness to dispose of waste in its place, not in the place provided by the DLHKP of Kediri City. And the lack of human resource knowledge about the handling of garbage.

\section{Garbage Collection activities.}

Based on the results of the study, it is known that waste collection in waste management by the Cleanliness and Hygiene Environmental Service has not been carried out properly considering that garbage collection cannot be carried out from waste sources because there is still a lot of garbage in residential areas that cannot be transported, in addition to taking garbage from waste sources to other places. the temporary shelter cannot be implemented by the officers in accordance with the schedule for collecting waste from the waste source. (Mahda Wahdatunnisa; 2019)

\section{Garbage removal activities.}

Based on the results of the study, it is known that waste collection in waste management by the DLHKP of Kediri City has not been carried out properly considering the lack of adequate facilities and infrastructure in transferring waste from the collection point to the final processing site (TPA), as well as the lack of adequate equipment in transferring waste. such as containers, durms, trucks, arm rolls, waste transporters. This is because $65 \%$ of the condition of the waste transport equipment has been in operation for more than 16 years, the current condition of the 
vehicle is damaged and ineffective for operation. (Yenik Pujowati:2021) Journal of Urban Sociology, Volume 4/No.1/April 2021.

\section{Transport Activities}

Based on the results of the study, it is known that the collection of waste in waste management by the Department of the Environment, Hygiene and Gardening of the City of Kediri has not run efficiently, due to the limitations of the waste transport fleet. On the other hand, waste management services from TPS 3R to TPA have been directed to timely transport of waste. But the weakness of TPS $3 R$ indicator only labor shortage and the difficulty to find workers at the polling station for which handled $3 \mathrm{R}$ associated with the smell of garbage with very minimal wages.

\section{Waste Management Activities}

Based on the results of the study, it is known that the collection of waste in waste management by the Department of the environment, hygiene and parks in the City of Kediri has not been carried out properly considering the lack of processing waste in the landfill and the management of hazardous and toxic waste has not been carried out specifically. awareness of citizens to separate organic and non-organic waste bins societies tend to incorporate both organic and non orangik into the same plastic bag.

\section{CONCLUSION}

1. The effectiveness of community-based waste management policies in Kediri City shows that the role of DLHKP is to provide understanding to the community through; socialization activities, counseling, training, collection, storage, sorting provided by the village to the community on how to use waste by sorting and treating organic and inorganic waste at the household waste scale have been running optimally. On the other hand, this is due to the fact that there are still few people who take part in the waste management process because people do not really understand the concept of waste management. But the government should increase the commitment in implementing policies and invite the community to engage further in awareness of keeping the environment. The current bureaucratic structure is sufficient to understand standard operating procedures in implementing policies, there must still be efforts to equalize understanding between all parties in implementing waste management with the $3 \mathrm{R}$ concept in Kediri City.

2. The effectiveness of community-based waste management policy Kediri shows infrastructures existing waste management include; the collection, removal stage, the stage of transportation, final disposal (landfill) is well defined. The Kediri City Government has provided a container according to the type of waste. Related infrastructure waste transportation patterns Kediri has not run effectively and efficiently, this is due to the lack of the limitations of human power or the number of personnel is not proportional to the amount of waste generated. Limitations waste carrier fleet, the average condition of the tool transporting waste has been in operation more than sixteen years and the current state of broken and ineffective for operationalized. Forty percent of the available containers in the TPS are porous, so they are not optimal enough to be operationalized as a garbage collection site.

\section{REFRENCES}

[1] Fallita R, W. et, al. 2021. Efeketivitas Kebijakan Pengelolaan Sampah Berbasis Tempat Pengelolaan Sampah $\begin{array}{lllllll}\text { Terpadu } \quad(T P S T) & 3 R & \text { di Indonesia. } & \text { PERSPEKTIF, } 10 & \text { (1): 195-203. }\end{array}$ https://ojs.uma.ac.id/index.php/perspektif/article/view/4296/3063

[2] Mahda Wahdatunnisa. 2019. Pelaksanaan Pengelolaan Sampaholeh Dinas Lingkungan Hidup Dan Kebersihan Kabupaten Pangandaran. Jurnal Moderat, Volume 5. No 2, Mei 2019, hlm 123-138.

[3] https://jurnal.unigal.ac.id/index.php/moderat.

[4] Nur Indrianti. 2016. Community-based Solid Waste Bank Model for Sustainable Education. Procedia - Social and Behavioral Sciences. Vol. 224 (2016) 158-166.

[5] https://www.sciencedirect.com/science/article/pii/S1877042816305158

[6] Peraturan Daerah Kota Kediri No. 3 Tahun 2015 Tentang Pengelolaan Sampah.

[7] Rezky Amelia Salinding, et, al. 2016. Efektivitas Pengelolaan Sampah Oleh Dinas Kebersihan Dan Pertamanan Kota Manado. Jurnal Administrasi Publik. Vol 3, No 41 (2016).

[8] Website: https://ejournal.unsrat.ac.id/index.php/JAP/article/view/14299.

[9] Utami, B. D. et. al. 2008. Pengelolaan Sampah Rumahtangga Berbasis Komunitas. Sodality: Jurnal Transdisiplin Sosiologi, Komunikasi, dan Ekologi Manusia| Vol.2 No.1 / April 2008, p 49-68.

[10] https://journal.ipb.ac.id/index.php/sodality/article/view/5893

[11] Undang-Undang Republik Indonesia No. 18 Tahun 2008 Tentang Pengelolaan Sampah.

[12] Peraturan Daerah Kota Kediri No. 3 Tahun 2015 Tentang Pengelolaan Sampah 
[13] Winarsih, N, W, E. et al. (2019). Efektivitas Pengelolaan Sampah di Kota Denpasar (Suatu Penelitian di Dinas Lingkungan Hidup dan Kebersihan Kota Denpasar). SINTESA: Jurnal Ilmu Sosial dan Ilmu Politik. 10 (2), pp.74-77. http://dx.doi.org/10.22225/sintesa.10.2.1536.74-77

[14] W. C. John. 2014. "Penelitian Kualitatif dan Desain Riset, Memilih diantara Lima Pendekatan,” Yogyakarta: Pustaka Pelajar.

[15] Yenik Pujowati. 2021. Kebijakan Pemerintah Daerah Dalam Meningkatkan Kinerja Pelayanan Kebersihan di Kota Kediri. Journal of Urban Sociology |Volume 4 /No.1 /April 2021.

[16] https://journal.uwks.ac.id/index.php/sosiologi/article/view/1485

[17] Yenik pujowati, et al. 2019. Management Policy In Kediri City The Effectiveness Of The Performance Of Community Based $3 r$ Waste. International Journal of Mechanical Engineering and Technology (IJMET). Volume 10, Issue 02, February 2019, pp.1726-1732, Article ID: IJMET_10_02_178. 